\title{
Ethical proceedings against dentists in Espírito Santo for infringements to the code of dental ethics
}

Karina Tonini dos Santos PACHECO Manoelito Ferreira SILVA JUNIOR Naiara Ribeiro MEIRELES

Department of Social Medicine, School of Dentistry, Universidade Federal do Espírito Santo - UFES, Vitória, ES, Brazil.

Declaration of Interests: The authors certify that they have no commercial or associative interest that represents a conflict of interest in connection with the manuscript.

Corresponding Author:

Karina Tonini dos Santos Pacheco

E-mail: kktonini@yahoo.com.br

http://dx.doi.org/10.1590/1807-3107BOR-2014.vol28.0002

Submitted: May 26, 2013

Accepted for publication: Nov 11, 2013

Last revision: Dec 17, 2013
Abstract: Just like any other profession, dentistry requires ethical and moral responsibilities that must be fulfilled, and the duty of every professional is to meet his obligations under the law. In light of the Código de Ética Odontológica (CEO - Code of Dental Ethics), this research aims to expound on the ethical violations committed by dentists in their practice, according to the ethical review process proposed by the Conselho Regional de Odontologia do Estado do Espírito Santo (CRO/ES - Regional Council of Dentistry of the State of Espírito Santo). The study is both retrospective and descriptive, using a quantitative approach. Data collection comprised all the ethical proceedings filed at the CRO/ES, between the years 2000 and 2011. Considering the 529 cases examined, the most frequent reason for infringement was illicit advertising $(39.7 \%)$, followed by technical error (18.7\%), irregular registration (16.8\%), patient/ professional relationship (11.3\%) tax lien foreclosure (6.6\%), professional/professional relationship (4.0\%), irregular/illegal cover up practice $(0.9 \%)$, consumer relations $(0.8 \%)$, failure to provide care $(0.6 \%)$, false certification $(0.4 \%)$, and disrespect for authority and colleagues $(0.2 \%)$. Most (59.2\%) of the dental surgeons (DSs) involved were male, 35.5\% were between 31 and 40 years of age, $85.8 \%$ had graduated over five (5) years prior, and $73.2 \%$ were general practitioners. Only $22(4.2 \%)$ cases went to trial, resulting in $8(36.4 \%)$ acquittals and $14(63.6 \%)$ convictions. The most commonly applied penalties were private warning + pecuniary penalty (8 or $57.1 \%$ ). It was concluded that the CEO must be followed with more discipline, and that professionals should seek information about their duties and obligations under the law, on behalf of patient welfare.

Keywords: Ethics; Dentistry; Liability, Legal.

\section{Introduction}

Ethical problems in dental practice occur routinely and may involve aspects related to the patient, organization of health services, relationship with colleagues and the society as a whole. However, professionals are not always prepared to deal with ethical aspects; this could lead them to experience ethical conflicts in their professional practice. ${ }^{1}$

After the federal and regional dental councils were established, dentistry came to be regulated by these organizations, whose main role is to supervise dental professional ethics throughout the country, supervising and working to improve the practice of dentistry. ${ }^{2}$ Members of 
the federal and regional dental councils organized the Código de Ética Odontológica (CEO - Code of Dental Ethics). The CEO establishes the fundamental principles that guide the work of dentists in their professional practice, which should be performed to benefit the health of human beings, the community and the environment. ${ }^{2}$ The CEO regulates the rights and duties of professionals, organizations and health insurance companies registered at the dental councils, according to specific responsibilities. Ethical guidelines must be followed by dentists and other auxiliary professions regulated by the Conselho Federal de Odontologia (CFO - Brazilian Federal Council of Dentistry), regardless of their job or role, as well as by companies. ${ }^{3}$

The Código de Processo Ético Odontológico (Code of Dental Ethics Legal Proceedings) was established and regulated by Resolution CFO no. 59/2004, aiming at looking into possible offenses to CEO regulations, and to applying the proper penalties through ethical proceedings. ${ }^{4}$ With this in mind, it is important to analyze the current stage of ethical legal actions filed at the Conselho Regional de Odontologia do Espirito Santo (CRO/ES - Regional Council of Dentistry of the State of Espírito Santo), aiming to characterize the ethical infringements of dentists in the state of Espírito Santo.

\section{Methodology}

This retrospective descriptive documentary study uses a quantitative approach. It was approved by the Institutional Review Board of the Universidade Federal do Espírito Santo (UFES - Federal University of Espirito Santo) under Protocol no. 205/11. The documentary analysis of the study was conducted according to preexisting data from the CRO/ES, following the ethical principles of Resolution no. 196/96 of the Conselho Nacional de Saúde (CNS - Brazilian National Health Council). The retrospective data were collected from all ethical proceedings filed at the $\mathrm{CRO} / \mathrm{ES}$ between 2000 and 2011. For the purpose of better categorizing the matter at hand, the infringements were classified according to the following variables: reason for the infringement, nature of accusation, stage of the legal action, result of judgment, penalty applied, gender, age range, time of professional practice and the dentist's specialty. The study excluded proceedings that did not contain information important to the study, as well as those involving dental surgeons (DSs) with more than one specialty, insofar as this would impair perception of the specialties more involved in the infringements.

The quantitative analysis of the data was performed on the Statistical Program Software - SPSS ${ }^{\circledR} 17.0$ (SPSS Inc., Chicago, USA), by distribution of frequencies and percentages. The researchers did not have access to the lawsuits during data collection, only to the information needed to perform the study, and made available on digitized files from the dental council.

\section{Results}

A total of 529 lawsuits were analyzed. Most of the DSs involved ( $\mathrm{n}=59.2 \%$ ) were male; $35.5 \%$ were 31 to 40 years of age; $25.9 \%$, 20 to 30 years old; $20.8 \%$. 41 to 50 years old; $10.6 \%: 51$ to 60 years old; and $7.2 \%$, over 60 years old. A total of 454 (85.8\%) DSs had graduated over five years prior and 75 (14.2\%) less than 5 years prior.

Concerning the academic institutions of the DSs, $230(43.5 \%)$ graduated from the UFES, 113 (21.4\%) from institutions in the state of Minas Gerais, 84 (15.9\%) from Rio de Janeiro, 28 (5.3\%) from Faculdades Integradas de São Pedro (FAESA), 20 (3.8\%) from São Paulo and $54(10.2 \%)$ from other states. Only 142 (26.8\%) of the DSs involved in infringements graduated with a specialty (Table).

The most frequent reason for infringement was illicit advertising (39.7\%), followed by technical error (18.7\%), irregular registration (16.8\%), patient/professional relationship (11. 3\%), tax lien foreclosure (6.6\%), professional/professional relationship (4.0\%), irregular/illegal cover up practice $(0.9 \%)$, consumer relations $(0.8 \%)$, failure to provide care $(0.6 \%)$, false certification $(0.4 \%)$ and disrespect for authority and colleagues $(0.2 \%)$.

Figure 1 shows the nature of the accusation.

Concerning the stage of the lawsuits, 332 (62.8\%) had been shelved, 173 (32.7\%) were underway and $22(4.2 \%)$ had been judged. In one case $(0.2 \%)$, the $\mathrm{CRO} / \mathrm{ES}$ refused to make the accusation, and, in one case $(0.2 \%)$, the dentist involved died.

The lawsuits were shelved for the following reasons: the DSs reformed themselves (32.8\%), there was no confirmation of possible infringement $(27.3 \%)$, 
Table. Percent distribution of lawsuits analyzed at the CRO/ ES between 2000 and 2010, according to the dentists' specialty. Source: CRO-ES, Vitória, 2011.

\begin{tabular}{lcc}
\hline Variable & $\mathrm{n}$ & $\%$ \\
\hline Academic level & & \\
$\quad$ Generalist & 387 & 73.15 \\
Specialist & 142 & 26.85 \\
\hline Total & 529 & 100 \\
\hline Specialties & & \\
Functional Jaw Orthopedics & 2 & 1.41 \\
Dental Radiology and Imagining & 6 & 4.23 \\
Orthodontics and Dentofacial Orthopedics & 22 & 15.49 \\
Periodontology & 15 & 10.56 \\
Endodontics & 9 & 6.34 \\
Restorative Dentistry & 4 & 2.82 \\
Pediatric Dentistry & 4 & 2.82 \\
Orthodontics & 41 & 28.87 \\
Maxillofacial Surgery and Traumatology & 12 & 8.45 \\
Implantology & 15 & 10.56 \\
Prosthodontics & 12 & 8.45 \\
\hline Total & 142 & 100 \\
\hline
\end{tabular}

conciliation (22.7\%) and the Termo de Ajuste de Conduta (TAC - Conduct Adjustment Instrument) (17.2\%). In compliance with the TAC, the dental surgeon's pledges to the CRO that he will not repeat the act that led to the accusation. Among the lawsuits judged, 14 (2.6\% of the total number) resulted in a conviction and $8(1.6 \%$ of the total number) ended in acquittal. Figure 2 shows the penalties applied to the professionals involved in infringements, according to their conviction.

\section{Discussion}

The present study revealed that most of the DSs involved in infringements were male and that most of the lawsuits judged resulted in conviction, insofar as most of the infringements were illicit advertisement, and most of the charges were ex officio, i.e., lodged by the CRO/ES itself. These data corroborate the results of a similar study by Garcia and Caetano, ${ }^{4}$ in which $79.9 \%$ of the DSs were male, $62.3 \%$ of the convictions involved the application of penalties, the predominant infringement was illicit advertisement (56.5\%), and most charges were ex officio (63.3\%).

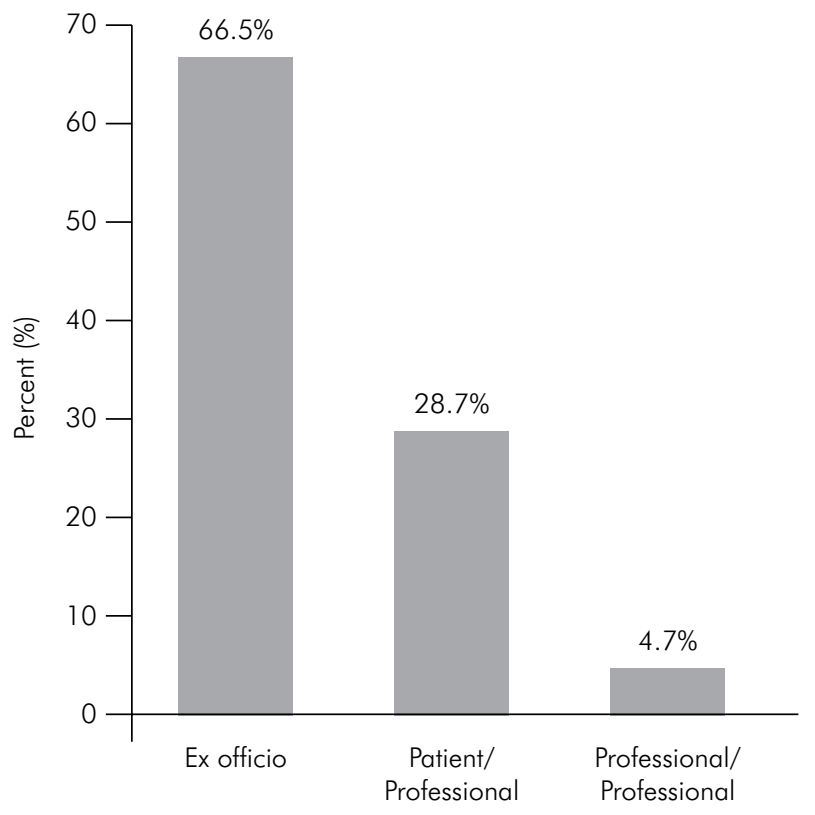

Figure 1. Percent distribution of lawsuits analyzed at the CRO/ES between 2000 and 2010, according to the nature of the accusations. Source: CRO/ES, Vitória, 2011.

The CEO, ${ }^{3}$ Chapter XIV, Section I, foresees some conditions for advertisement in Dentistry, including Article 33, which states that the name and identification number of an individual or company should necessarily be communicated and disclosed, as well as the name of the dental profession and other regulated auxiliary professions. These conditions must be observed by the professionals.

However, in the study by Garbin et al. ${ }^{5}$ in the city of São Paulo, the authors evaluated 178 signboards, of which only $44.9 \%$ displayed all the compulsory items, according to the CFO. The item less displayed on the signboards was the CRO registration number. Concerning the fields of practice, the procedure and the treatment techniques, 37.6\% of the signboards included these specifications, yet $59.7 \%$ of the signboards declaring these items did not display the designation, "general practitioner" or specialty degree. Since most accusations were ex officio, the present study highlighted the importance of the CROs, whose responsibility it is to supervise professional ethics, to care for the proper ethical performance of dentistry and to further the good reputation of the profession and its certified professionals. 


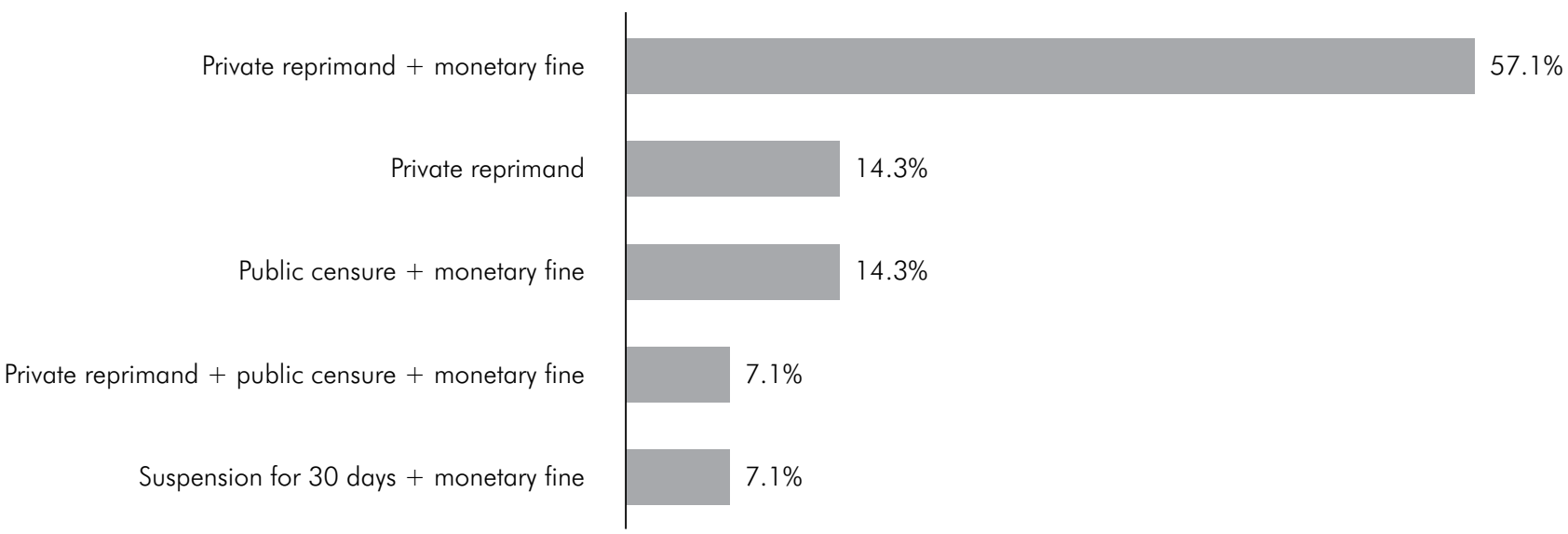

Figure 2. Percent distribution of lawsuits analyzed at the CRO/ES between 2000 and 2010, according to the penalties applied to dentists. Source: CRO/ES, Vitória, 2011.

In addition, illicit advertising may be related to the nature of the accusation ex officio, since the advertisement implies greater visibility, and may be promoted by the communication media. A similar relationship was recounted in the study by Marques Filho and Hossne, ${ }^{6}$ in the proceedings to revoke a medical professional's license to practice in the state of São Paulo. The authors mentioned that the nature and severity of the facts leading to revocation of a professional license are frequently published and disseminated in the media, partly explaining the fact that the most frequent accusations stem from ex-officio actions.

General practitioners represented the dental class most involved in infringements, followed by orthodontists. A study conducted on 70 accusations from the Conselho Regional de Odontologia do Piauí (CRO/PI - Regional Council of Dentistry of the State of Piauí), ${ }^{7}$ revealed that orthodontics was the most frequent specialty involved, followed by maxillofacial surgery and endodontics. The most frequent reasons for infringements were also illicit advertisement and infringement on services rendered.

However, these data must also be analyzed according to the number of professionals in the market. Most dentists registered in the CRO/ES are not specialists, and most registered specialists are orthodontists. This may explain the results presented in Table 1 . Similarly, most dentists in this study were 31 to 40 years of age, which reflects the prevailing age range of professionals working in the state of Espírito Santo. ${ }^{8}$
The present results demonstrated that, among the 529 accusations lodged at the CRO/ES, 152 (28.7\%) were by a patient against the professional. This goes to prove that the health market, previously considered as "untouchable", currently receives several accusations, both from users and fellow professionals. Therefore, it is important to know not only the target of the consumer charges, but also the reasons why professionals and dental companies are being charged. ${ }^{9}$

Civil suits have been more frequent than criminal proceedings, because the patients are usually more interested in receiving indemnity than seeing the professional condemned to a penalty of curtailment of liberty. Certainly, the CEO has brought a new order to relationships between dentists (service providers) and patients, who are now more aware of their rights as consumers. ${ }^{10}$

Melani et al. ${ }^{10}$ analyzed 41 initial petitions of civil suits filed against dentists and observed that 97.50\% involved indemnity proceedings, often called Indemnity Action or Action for Damages. It should be highlighted that, overall, $19.51 \%$ of the patients who had filed legal actions had initially sought out the regional dental council ethics committee. This demonstrates that is it possible for the ethics committees of regional councils to act as conciliation boards, thereby obviating legal action.

Among the lawsuits analyzed, the second most frequent motive for pressing charges was technical 
error, with 99 (18.7\%) of the accusations. There were also significant charges concerning the patient-professional relationship.

These results agree with a study based on data collected from the Fundação de Proteção e Defesa do Consumidor (Procon - Consumer Protection Agency) of Campina Grande-PB, which revealed a total of 82 lawsuits related to dentistry, involving the dentist, dental insurance companies and low-cost health clinics. The main complaints reported were the poor services delivered (56.1\%) and the abusive costs (15.9\%). ${ }^{9}$ In the present study, only $0.8 \%$ of the accusations involved a consumer- or money-related reason.

It is widely known that the delivery of autonomous services on the part of professionals (including physicians, dentists and other health professionals) generally involves the obligation of best efforts. ${ }^{11}$ The respective regulation is set forth in $\S 4$ of Article 14 of the Código de Defesa do Consumidor (CDC - Brazilian Consumer Defense Code) ${ }_{1}^{12}$ which establishes that the personal responsibility of these professionals will be analyzed by "proof of guilt."

Conversely, Article 951, related to Articles 948, 989 and 950 of the Código Civil, ${ }^{13}$ (Brazilian Civil Code) establishes that indemnification is due when the agent causes damage due to "negligence, imprudence or lack of skill" while exercising one's professional practice. It is the duty of a dentist when practicing in his clinic to "establish and maintain updated records of patients and file them" (Article. 5, Clause VIII, of the CEO), ${ }^{3}$ as well as to provide a copy of these records when requested (Clause XVI). Even dental laboratory technicians are required to record and file any technical-laboratory procedures performed (Clause XVII).

Even though there is no consensus among jurists in regard to the classification of a professional's obligation - whether of best efforts or to achieve the best result, or even both - this becomes irrelevant, and the professional must present all available proof in the case of a lawsuit. The dentist should always be ready and interested in proving his or her trustworthiness, knowledge and technical skills, as well as dedication to the patient and patient-related organization. ${ }^{14}$

With this in mind, self-employed professionals have the duty to indemnify damages caused by the services they deliver. For this reason, the dentist must organize the patient records in his clinic on a daily basis, and must keep all the information on any treatments performed on file, demonstrating as diligently as possible all the clinical and technical work that was undertaken. ${ }^{10}$

However, despite all the discussion on the subject, most professionals are still not prepared to deal with these complaints, in all respects. It is relatively straightforward to measure a gain in knowledge, but more challenging to measure a change in attitude. ${ }^{15}$

A study conducted in Mexico ${ }^{16}$ revealed that the most frequent irregularities related to dentistry were: lack of communication between the oral health professional and the patient, a tendency to raise a patient's hopes unfoundedly, improper use and handling of materials, unduly indicated procedures and clinically unfeasible treatments. The same authors further observed such irregularities as unmet obligations absence of clinical records and informed consent, patients exposed to unnecessary risks, and patient dissatisfaction with the results, as well as the professionals' unfamiliarity with the Health Law and the Mexican Official Guidelines that regulate dental practice and professionals' relationship with patients.

According to the $\mathrm{CEO},{ }^{3}$ ethical infringements include performing or suggesting treatment that is either unnecessary or for which the professional is not skilled, and initiating dental procedures or treatments without previous consent from the patient or caretaker, except in cases of urgency or emergency.

Good professional/patient communication, including appropriate conveyance of information on the treatment, and consequent adequacy of patient expectations to anticipated outcomes is fundamental for the success of any work. Concerning the conveyance of information, it was observed that some professionals do not offer the necessary and detailed information $^{16,17,18}$ on the procedures to be performed, or else, inform the patients only in more complex cases. This is a matter of concern, since it is fundamental that the correct explanation of what the respective treatment involves be communicated to the patient, in today's clinical practice. In the city of Rio das Pedras-SP, it was reported that dentists did not have the habit of conveying adequate information to patients, consequently leading to reports of dissatisfaction. ${ }^{17}$ 
Among the reasons for infringement, that of irregular records was also very frequently reported, namely, 89 (16.8\%). In a study conducted in Piracicaba-SP, Paranhos et al. ${ }^{19}$ reported that $60 \%$ of dental nurses were not registered at the Conselho Regional de Odontologia de São Paulo (CRO/SP-Regional Council of Dentistry of theState of São Paulo). Another study revealed that 38 (41.30\%) of dentists were not aware that dental nurses should be registered at the CRO/SP, and 37 (40.22\%) were not aware that dentists are responsible for the work of their auxiliary personnel. ${ }^{20}$

Other lawsuits analyzed in this study were filed without being judged. Among the reasons, 22.7\% were filed due to conciliation. Similarly, a study conducted by Cavalcanti et al. ${ }^{9}$ revealed that $58.5 \%$ of the lawsuits filed with the Procon of Campina Grande-PB also ended in agreement between the parties.

An important consideration is that the relationship between professionals and patients is of a technical nature and is fundamental for healthcare quality. This relationship is described in the literature as "light technology," expressed as a process of communicating, of relationships and bonds that fulfill the needs of users requiring health actions. ${ }^{21}$ Thus, dentists must learn to listen to their patients, understand their body language and learn techniques that will make their patients feel good and trustful. ${ }^{22}$

Article 45 of the $\mathrm{CEO}^{3}$ provides for the following penalties for ethical infringements: private reprimand conveyed in private, private censure made in private, public censure made in an official publication, up to 30 (thirty) days suspension of professional practice,

\section{References}

1. Amorim AG, Souza ECF. Ethical problems experienced by dentists: dealing with bioethics to wide the view on the daily professional practice. Cien Saude Colet. 2010 May;15(3):869-78. Portuguese.

2. Oliveira FT, Sales Peres A, Sales Peres SHC, Yarid SD, Silva RHA. Odontological ethics: knowledge of the students and dentists on the ethical aspects of the profession. Rev Odontol UNESP. 2008 Jan-Mar;37(1):33-9. Portuguese.

3. Conselho Federal de Odontologia. Código de Ética Odontológica. Resolução 42 (20 de maio de 2003). Rio de Janeiro: CFO; 2003.

4. Garcia SJ, Caetano JC. The odontological ethics code infractions: a study on the proceedings ethics professional of the surgeon dentists in Santa Catarina state. Rev Odontol Clin Cient. 2008 Oct-Dec;7(4):307-13. Portuguese. and revocation of the professional's license to practice ad referendum of the CFO. In addition to the disciplinary penalties, a monetary fine may also be applied, between one (1) and twenty five (25) times the value of the professional's annual fees and twice as much in the case of recurrence, as determined by the regional dentistry councils. The most frequently applied penalty found in this study was private reprimand with a monetary fine. In the study by Garcia and Caetano, ${ }^{4}$ the most widely applied penalty was only a private reprimand, followed by public censure in an official publication, and a monetary fine.

Therefore, it becomes clear that adequate knowledge of rights and duties, and compliance with the CEO, are fundamental for the proper practice of any profession, including professions related to health and collectivity, such as medicine and dentistry. ${ }^{23}$ It is important for dental professionals to display an ethic character in their daily routine, and to interpret and understand the code of ethics soundly, always aiming to respect and follow it, without the overbearing influence of fear arising from infringement-related punishment. ${ }^{24}$

\section{Conclusion}

The CEO should be followed with greater discipline, and professionals should seek more information on their duties and obligations, under the law, toward furthering patient health. In general, ethical infringements compromise the goal of exercising one's profession and may demonstrate a lack of responsibility of dental professionals toward society.

5. Garbin AJI, Orenha ES, Garbin CAS, Gonçalves PE. Publicity in dentistry: assessment of the ethical aspects involved. Rev Gaucha Odontol. 2010 Jan-Mar;58(1):85-9. Portuguese.

6. Marques Filho J, Hossne WS. Análise bioética dos processos de cassação do exercício profissional médico no Estado de São Paulo. Rev Assoc Med Bras [Internet]. 2008 May-Jun [cited 2013 Oct 14];54(3):214-9. Available from: http://www.scielo.br/pdf/ramb/v54n3/a13v54n3.pdf

7. Dantas Neta NB Torres PF Nogueira LT Carvalho CMRS. Civil liability of dentists based on reports filed to the regional council of dentistry. Braz J Oral Sci. 2011;10(2):109-12.

8. Conselho Federal de Odontologia [homepage]. Brasília (DF): Conselho Federal de Odontologia; 2013 [cited 2013 Aug 16]. Available from: cfo.org.br 
9. Cavalcanti AL, Silva AL, Santos BF, Azevedo CKR, Xavier AFC. Dentistry and the Consumer Defense Code: analysis of the lawsuits against dentists and dental insurance plans in Campina Grande, PB, Brazil. Rev Odontol UNESP. 2011 Jan-Feb;40(1):6-11. Portuguese.

10. Melani RFH, Oliveira RN, Tedeschi-Oliveira SV, Juhás R. Legal devices and arguments mostly used in civil lawsuits: casuistry analysis in dentistry. RPG Rev Pos Grad. 2010 Jan-Mar;17(1):46-53. Portuguese.

11. Jessri M, Fatemitabar SA. Implication of ethical principles in chair-side dentistry. Iran J Allergy Asthma Immunol. 2007 Feb;6(5 Suppl):53-9.

12. Brasil. Código de Defesa do Consumidor. Lei n 8078, de 11 de setembro de 1990. Brasília (DF): Ministério da Justiça; 1990.

13. Pinto ALT, Windt MCVS, Céspedes L. Código Civil. 53th ed. São Paulo: Saraiva; 2002. 1994 p.

14. Katrova L. Ethical, legal, and professional foundations of the autonomous regulation of the dental profession, the case of Bulgaria. J Int Med Assoc Bulg. 2010;16 (book 4):70-6.

15. Sharp HM, Kuthy RA. What do dental students learn in an ethics course? An analysis of student-reported learning outcomes. J Dent Educ. 2008 Dec;72(12):1450-7.

16. Estrada JT. Ethics: a problem for odontologists. Acta Bioeth. 2006 Jan;12(1):75-80. Spanish.

17. Garbin CAS, Garbin AJI, Dossi AP, Macedo L, Macedo V. Dental treatment: information's transmitted at pa- tients and causes of dissatisfaction. Rev Odontol UNESP. 2008 Apr-Jun;37(2):177-81. Portuguese.

18. Vassão SAS, Carvalho RB, Medeiros UV, Santos KT. [Judicial risk prevention on dental practice: what the dental surgeon should know]. Rev Assoc Paul Cir Dent. 2009 Sep-Oct; 63(5):390-4. Portuguese.

19. Paranhos LR, Tomasso S, Ricci ID, Siqueira DF, Scanavini MA. [Analysis of the legal atributes and implications of professional dental assistants: view of the assistant him]. Rev Gaucha Odontol. 2009 Jan-Mar;57(1):77-85. Portuguese.

20. Coelho MP, Melo LSV, Carvalho CM. Legal dentistry aspects of the professional practice between just-formed. UFES Rev Odontol. 2008;10(4):4-8. Portuguese.

21. Merhy EE, Onocko R. Agir em Saúde: um desafio para o público. São Paulo, Buenos Aires: Hucitec, Lugar Editorial; 1997. 385 p.

22. Graskemper JP. A new perspective on dental malpractice: practice enhancement through risk management. J Am Dent Assoc. 2002 Jun;133(6):752-7.

23. Silva RHA, Musse JO, Melani RFH, Oliveira RN. Surgeon dentist's civil liability: the technical assistant's importance. Rev Dent Press Ortod Ortop Facial. 2009 NovDec;14(6):65-71. Portuguese.

24. Santos NB, Garbin CAS, Moimaz SAS, Saliba NA. Falta de ética no relacionamento profissional. Rev Assoc Paul Cir Dent. 2004 Jan-Fev;58(1):35-7. Portuguese. 